УДК 338.24

JEL Classification: H 61

О. С. БОНДАРУК,

acniparm,

Національна академія статистики, обліку та аудиту

\title{
Класифікаційні особливості бюджетних елементів економічної безпеки
}

\begin{abstract}
В статті проаналізовано теоретичні аспекти економічной безпеки у взасмозв 'язку з такими бюджетними елементами як "бюджетні інтереси" i "бюджетні потреби". Обтруттовано, щзо категорії "бюджетні інтереси" $і$ "бюджетні потреби" посідають ключові позииії в теорії економічної безпеки в бюджетній сфері, оскільки відіграють провідну роль в прочесі вибору стратегій й̈ забезпечення. Здійснено класифікацію бюджетних інтересів за різними ознаками в контексті їх впливу на економічну безпеку держсави.
\end{abstract}

Ключові слова: економічна безпека, бюджетні інтереси, бюджетні потреби, ризики, загрози, суб' 'єкти інтересів.

Актуальність теми дослідження. Стабільний розвиток національної економіки, іiі ефективність $і$ конкурентоздатність на внутрішньому і світовому ринках тісно пов' язані 3 економічною безпекою країни. Для гарантування державної стратегії економічної безпеки необхідно враховувати зміни економічних і політичних реалій. В сучасних умовах зростає роль бюджетної політики у вирішенні економічних та соціальних проблем, що потребує відповідного фінансового забезпечення. Ії реалізація здійснюється шляхом бюджетної децентралізації, насамперед передачі місцевим бюджетам видатків державного бюджету за окремими бюджетними програмами, у сфері освіти, охорони здоров'я, житлово-комунального господарства. Проте на сьогодні вимагають вирішення проблеми зміцнення доходної бази бюджетів, встановлення прозорих процедур надання бюджетних трансфертів. Для ефект ивного управління економікою важливим $\epsilon$ наявність сучасних науково-методологічних підходів до оцінювання її потенціалу економічної безпеки. Важливість проблем, пов'язаних із бюджетною системою та особливостями впливу бюджетних елементів на підвищення ефективності механізмів економічної безпеки держави, обумовлює актуальність і своєчасність теми дослідження.

Аналіз останніх досліджень і публікацій. Теоретичним і практичним проблемам економічної безпеки приділено достатньо уваги. У вітчизняній і зарубіжній економічній науці склалися різні напрями досліджень проблем економічної безпеки, як на рівні країни, так і на рівні регіону. Загальнотеоретичні, методологічні та науково-практичні дослідження з проблем економічної безпеки представлені у працях таких вчених як Л. Абалкін [1], О. Барановський [2], М. Срмошенко [3] та ін. Проблеми розвитку державного та місцевих бюджетів досліджували такі вітчизняні вчені як Т. Бондарук [4], О. Кириленко [5], I. Луніна [6] та ін., які зосереджували увагу в основному на проблемах формування міжбюджетних відносин. Проте оцінка бюджетної складової економічної безпеки розглядасться ними опосередковано, що й обумовило актуальність і необхідність подальшого розгляду питань стосовно визначення бюджетних елементів економічної безпеки та їх класифікаційних особливостей.

Метою статті $\epsilon$ дослідження питань теоретичного та прикладного характеру шодо визначення, систематизації, конкретизації бюджетних елементів економічної безпеки, а також іх багатоаспектна ктасифікація.

Основні результати дослідження. На сьогодні питання сталого економічного розвитку набувають особливої актуальності. Однією з умов його забезпечення $\epsilon$ наявність ефективної системи гарантування їх економічної безпеки. Зміна економіки під впливом ринкових механізмів обумовила виділення системи економічної безпеки в особливий об' єкт управління. При всій важливості економічних проблем на сьогодні відсутній єдиний підхід до визначення сутності та особливостей бюджетних елементів економічної безпеки, зокрема таких як "бюджетні інтереси" та "бюджетні потреби".

Категорії "бюджетні інтереси" і "бюджетні потреби" посідають ключові позиції в теорії економічної безпеки в бюджетній сфері, оскільки відіграють провідну роль в

(c) О. С. Бондарук, 2017 
процесі вибору стратегії ії забезпечення. Бюджетні інтереси визначають зміст і динаміку бюджетної політики держави, державну бюджетну стратегію. Процедура виявлення, визначення, систематизації, конкретизації і структуризації бюджетних інтересів $\epsilon$ базовим етапом організації системи забезпечення економічної безпеки в бюджетній сфері, оскільки саме бюджетні інтереси є рушійною силою розвитку і зміцнення бюджетноі системи в різних аспектах ï прояву. Оцінювання кризових ситуацій у бюджетній сфері пов'язане 3 виявленням і аналізом реальних і потенційних загроз економічній безпеці в бюджетній сфері в різних сегментах фінансової системи.

Розглянемо в першу чергу проблеми бюджетних інтересів як економіко-правовоі категорії з погляду її сутності і змісту. Для цього необхідно уточнити тлумачення самої категоріі "бюджетні інтереси". 3-серед нечисленних робіт, що найближче підійшли до розгляду проблеми бюджетних інтересів, виділимо дослідження К. А. Бутаєва [7]. Ним зроблено спробу привернути увагу до проблеми бюджетних інтересів 3 погляду розуміння їх сутності, а також надано аргументи на користь важливості дослідження цієї категорії з метою виявлення суперечливих інтересів і шляхів їх узгодження. Проте він не надає інформацію стосовно структури, класифікації, систематизації і конкретизації бюджетних інтересів, розглядає проблему в однополярному контексті, зосереджуючись на аналізі інтересів між рівнями влади в системі міжбюджетних відносин, досліджує суперечності в бюджетних інтересах, але не пропонує алгоритм їх узгодження на таких рівнях як державний, суспільний, особистий, а також у системі "внутрішні - зовнішні бюджетні інтереси".

3 погляду на завдання дослідження головним об' єктом нашої уваги в роботах К. А. Бутаєва є запропонована дефініція бюджетних інтересів, які є "соціальноекономічною фунщцією доходів і витрат багаторівневої бюджетної системи державних і муніципальних територіально-економічних утворень метою підтримки на необхідному рівні розвитку галузей життєзабезпечення, а також задоволення потреб соціальної сфери в центрі, в регіонах і на місцях" [7, с. 9]. Перш ніж розглянути це визначення, звернемося до з'ясування сутності і змісту поняття “інтерес" з погляду його лексичного, економічного і юридичного змісту

Аналіз словарних джерел дозволив виділити три підходи до визначення поняття "інтерес": інтерес як сукупність потреб; інтерес як мета; інтерес як вигода.

Але чіткого розмежування категорій “інтерес" i “потреба" досі немає. Їх подібність виявляється у схожості їх тлумачень: “інтереси - головний стимул людської діяльності”" i “"потреби є джерелом активності особи". Різниця між ними виражається в розумінні інтересів як уваги до чогось значного, важливого, необхідного, корисного або того, що здається таким, а потреб - як бажання мати щось значне, важливе, необхідне, корисне або те, що здається таким. Погоджуючись із тим, що інтерес людини обумовлюється лише певною потребою, вважаємо, що інтерпретація бюджетних інтересів як сукупності бюджетних потреб має право на існування.

Л. І. Абалкін розглядає інтерес як бажання суб'єкта досягти мети, наголошуючи, що “інтереси < ..> відображаються в свідомості людей у вигляді поставлених цілей і волевиявлення до їх досягнення" [1, с. 132]. У цьому контексті бюджетний інтерес, представлений системою бюджетних цілей, дозволяє викласти уявлення про предмет (у нашому випадку про бюджет), яким він повинен бути з точки зору носіїв інтересів, щоб задовольнити потреби і принести певну вигоду або користь суб' єктові інтересів. Наприклад, "бюджетний інтерес полягає в тому, щоб досягти максимальних обсягів доходної частини бюджету". В цьому випадку мету "максимізації доходів бюджету" визначає бюджетний інтерес. Такий підхід до інтерпретації цієї категорії насамперед спрямований на виявлення шляхів реалізації інтересів. У зв'язку з цим визначення бюджетних інтересів як сукупності бюджетних цілей $є$ нераціональним.

Найбільш поширеним тлумаченням інтересу є "вигода", "користь" або "доход". Це обумовлено намаганням науково обгрунтувати економічні джерела і стимули діяльності людини. I якщо допустити, що бюджетним інтересом $€$ доход, це викривить базові уявлення про бюджетну сферу як про систему, що не має на меті отримання фінансового доходу, і не відповідатиме сутності бюджету як інструменту, що дозволяє ефективно здійснювати функції держави з метою задоволення суспільних потреб у безпеці, соціальному забезпеченні, освіті, збереженні здоров'я. Такі терміни як "доход" або “вигода" не застосовні до бюджетної сфери, якщо звичне фінансове розуміння 
доходу не змінюється на доход соціальний або суспільний. У разі зміни у розумінні доходу суперечність між поняттями “доход" і “бюджет” нівелюється, і тоді бюджетні інтереси можливо трактувати як вигоди, але не фінансові, а насамперед суспільні.

В Законі України “Про основи національної безпеки України”, стаття 1, міститься визначення національних інтересів: це “життєво важливі матеріальні, інтелектуальні і духовні цінності українського народу як носія суверенітету і єдиного джерела влади в Україні, визначальні потреби суспільства і держави, реалізація яких гарантує державний суверенітет України та ії прогресивний розвиток" [8], що характеризує цей термін 3 юридичних позицій. Базове визначення цього терміна, надане у законі, відповідає одному з трьох вищезазначених класичних підходів до тлумачення категорії “інтерес".

Проте визначення бюджетних інтересів у нормативних документах України ми не знайшли.

Досліджуючи економічний аспект категорії “інтерес", відмітимо, що економічні інтереси $€$ однією із найбільш дискусійних категорій. Незважаючи на полеміку економістів, що належали до різних епох і наукових течій, практично всі вони сходяться в тому, що:

- економічні інтереси є рушійною силою економіки і проявом виробничих відносин;

- $\quad$ вони мають носіїв, якими $\epsilon$ особи або групи, об’єднані за певними ознаками (звідси властивість суб' єктності інтересів);

- iх основою є потреби суб'єктів;

- вони обумовлені комплексом матеріально-технічних умов відтворювального процесу, а також системою виробничих відносин, головною з яких $є$ форма власності на засоби виробництва.

Визначимо категорію "бюджетні інтереси" виходячи з того, що визначення має 1) бути універсальним для всіх носіїв бюджетних інтересів, 2) відповідати принаймні одному з трьох класичних підходів до тлумачення поняття “інтерес"; 3) відображати категорію з урахуванням іï істотних ознак і при цьому бути простим, ясним і повним.

Наше визначення категоріі "бюджетні інтереси" грунтуватиметься на першому підході до тлумачення "інтересу" (інтерес як сукупність потреб). Це обумовлено тим, що “усвідомлені суспільством, соціальними класами, групами та індивідами, потреби виступають як їх інтереси" [9].

Зурахуванням вищевикладеного вважаємо, що бюджетні інтереси-ије сукупність бюджетних потреб носіӥв інтересу, які реалізуються через бюджетну діяльність суб 'єктів, спрямовану на отримання певної вигоди через бюджет з метою забезпечення функціонування і розвитку суспільства і держсави, юридичних і фізичних осіб.

Базову схему дефініції бюджетних інтересів подано на рис. 1.

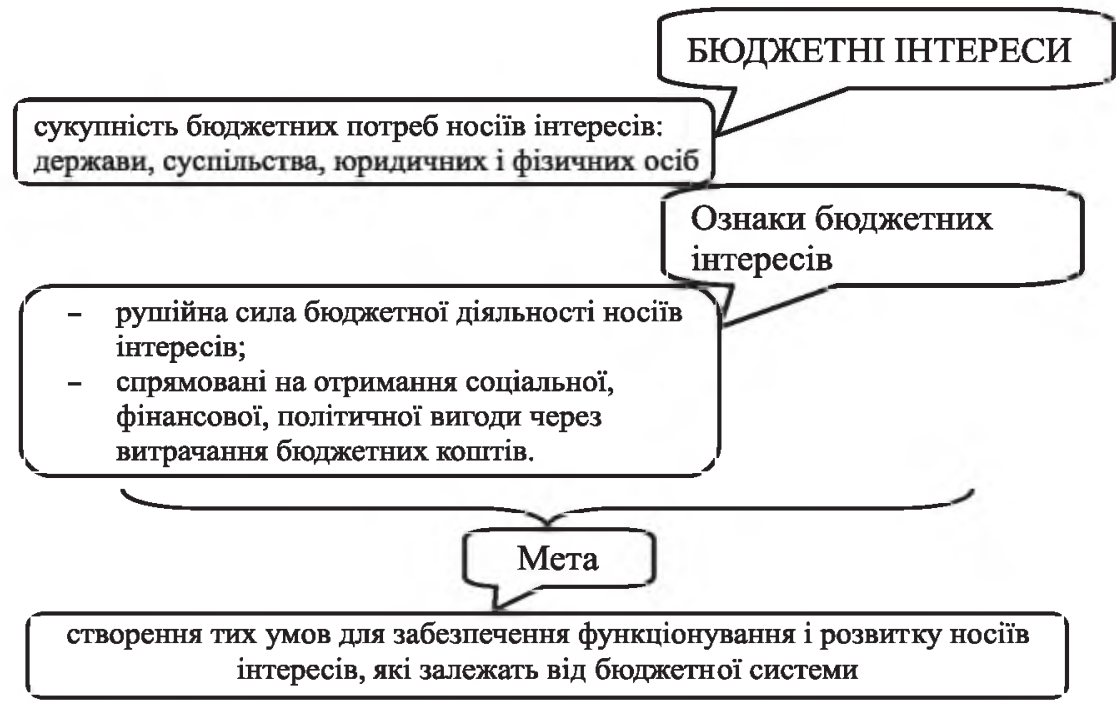

Рис. 1. Базова схема дефініції "бюджетні інтереси"

Джерело: складено автором 
У визначенні категоріі “бюджетні інтереси" крім базового підходу (“інтерес як потреба") використано два інших. Інтерес як мета виражений у визначенні мети - створення умов для функціонування і розвитку носіїв інтересів із використанням бюджетного інструментарію. "Тнтерес як вигода" використовується у визначенні ознак бюджетного інтересу як отримання соціальної, фінансової, політичної вигоди через бюджет.

Визначаючи бюджетні інтереси як сукупність бюджетних потреб, не можна не зупинитися на іншій значущій категорії теорії економічної безпеки в бюджетній сфері - "бюджетні потреб̆и". Дотримуючись фундаментального визначення потреби - "необхідність або недостатність будь-чого для підтримки життєдіяльності організму" [9], вважаємо за доцільне визначити бюджетні потреби як необхідність (потребу) в бюджетних коштах для забезпечення життєдіяльності індивіда, соціальної групи, суспільства, держави.

Бюджетні потреби держави - це необхідна передумова ії існування, так само як і бюджетні потреби суспільства - невід'ємна умова звичайного функціонування і розвитку соціуму. Рівень бюджетних потреб у цілому залежить від рівня політикоекономічного і суспільно-культурного розвитку держави. Розвиток цих сфер призводить до зародження нових бюджетних потреб, які з групи другорядних з часом переходять у розряд пріоритетних, що демонструє загальну закономірність розвитку бюджетних потреб з розвитком соціально-економічного і культурно-політичного прогресу у формі зростання потреб. Таким чином, всебічне вивчення потреб є важливою передумовою виявлення бюджетних інтересів і їх суперечностей, що дозволяє удосконалити бюджетне планування на всіх його рівнях.

3 погляду обсягу і структури бюджету бюджетні потреби поділяються на абсолютні (що виражають максимальний обсяг потреб у бюджетних коштах всіх суб'єктів) і реальні (ті, що можуть і об' єктивно повинні бути задоволені при оптимальному перебігу бюджетного процесу).

Як більшість економічних категорій, поняття “інтереси” є системним, таким, що включає структурні елементи. Їх логічне розташування і систематизація є важливим етапом дослідження бюджетних інтересів як елемента системи економічної безпеки в бюджетній сфері. Для вирішення поставленого завдання систематизації бюджетних інтересів скористаємося методом класифікації. Для проведення класифікації інтересів у бюджетній сфері необхідно сформулювати критерії класифікації. Критерій - це ознака, за якою проводиться класифікація. Інтереси доцільно класифікувати за такими критеріями: суб'єкт (носій) інтересів; територіальна приналежність суб' єкта інтересів; ступінь значення; величина вигоди; вид вигоди; характер дії; ступінь реалізації; імовірність реалізації інтересів; спрямованість інтересів; стадії бюджетного процесу; ступінь впливу суб' єкта на сутність інтересу (рівень субзалежності). Бюджетні інтереси держави можуть класифікуватися не тільки за носіями інтересів, а й по вертикалі - за рівнями влади, і по горизонталі - за суб'єктами одного рівня.

Візуальне відображення класифікації бюджетних інтересів представлено на рис. 2.

Істотне значення в процесі розроблення проекту концепції економічної безпеки в бюджетній сфері має дослідження бюджетних інтересів у межах ктасифікації за носієм інтересів. Пропонуємо здійснювати класифікацію бюджетних інтересів за суб’ єктами (носіями) інтересів за чотирма рівнями:

1. Бюджетні інтереси держави - тобто інтереси, носіями яких є державні і місцеві органи влади. Загальновизнаною формою декларування бюджетних інтересів держави $€$ їх декларування у вигляді юридичних документів.

Державні бюджетні інтереси спрямовані на оптимізацію реалізації державних функцій, таких як економічна, фінансова, соціальна, оборонна, екологічна, функції підтримки науки, культури, освіти і спорту. Декларування інтересу як державного, а також прагнення реалізувати його має бути спрямовано на підвищення ефективності виконання державою тих функцій, які інші суб'єкти виконувати не в змозі.

2. Бюджетні інтереси суспільства - це інтереси, спрямовані на задоволення суспільних потреб і формування повноцінного громадянського суспільства, спроможного відповідати за структурою, чисельністю, рівнем освіти і культури потребам демократичної держави із потужним економічним потенціалом. Реалізація цих інтересів $€$ основою соціальної функції держави. Очевидно, що реалізація соціальної політики відбувається шляхом фінансування з державного і місцевих бюджетів. 


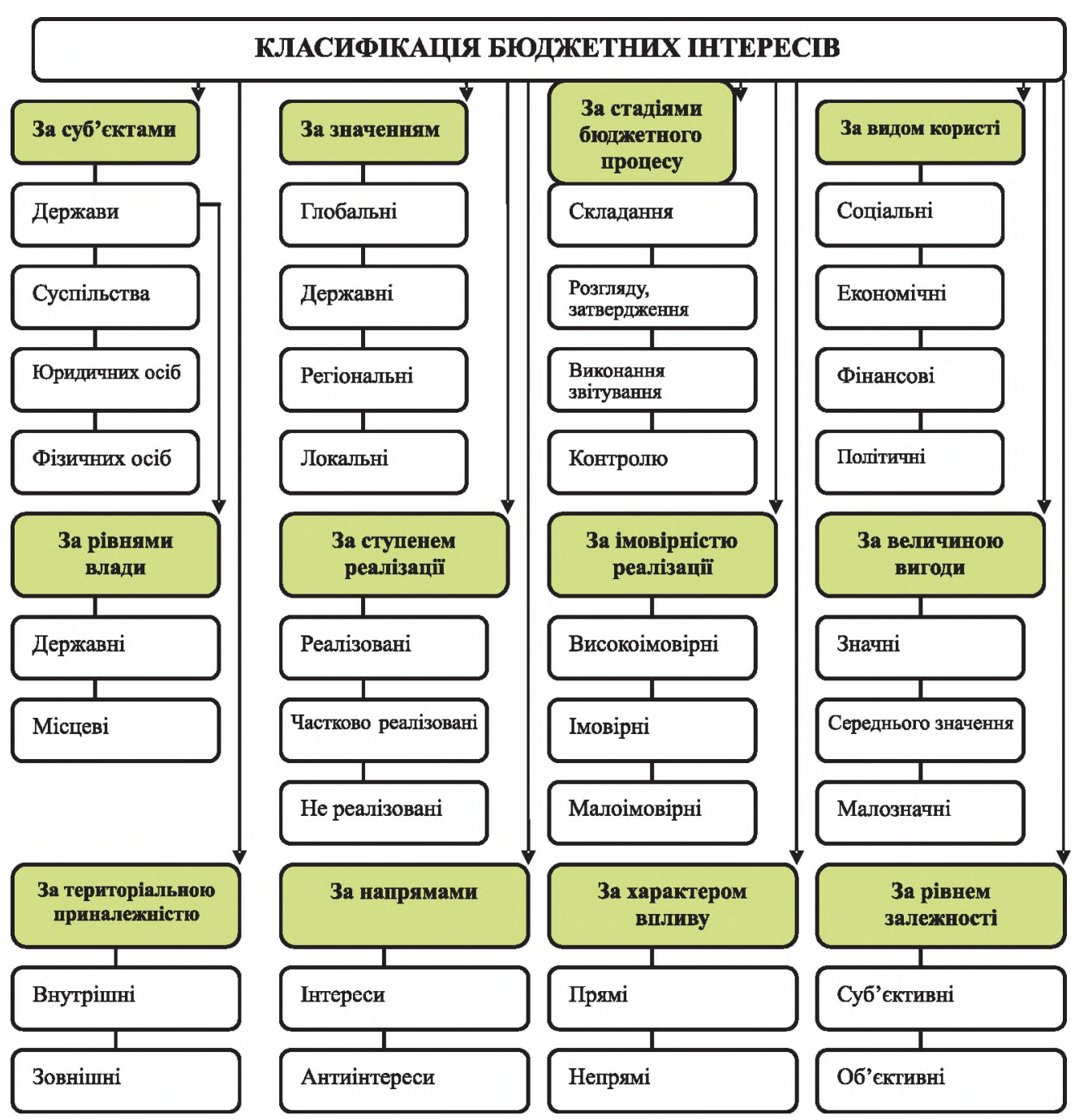

Рис. 2. Класифікація бюджкетних інтересів

Джерело: складено автором

Повноцінне фінансування бюджетних інтересів суспільства, так само як і ефективне використання бюджетних коштів, забезпечують формування повноцінного, висококультурного громадянського суспільства. Розуміння бюджетних інтересів суспільства не повинне обмежуватися лише увагою до фінансових обсягів статей соціального призначення. Бюджетні інтереси суспільства - це також можливість для залучення суспільства до бюджетного процесу, наприклад, через участь громадських організацій в обговореннях проектів бюджетів на черговий фінансовий рік або здійснення реального громадського контролю бюджетних організацій і державних органів стосовно витрачання бюджетних ресурсів.

На нинішньому етапі розвитку України суспільство не відіграє істотної ролі в процесі формування бюджету. Це обумовлено відсутністю у населення сформованої громадянської позиції, небажанням захищати власні інтереси і інтереси суспільства в цілому. Сьогодні велику частку в загальній структурі бюджетних інтересів мають інтереси держави, юридичних осіб і впливових громадян, що порушує баланс державносуспільних інтересів, необхідний для звичайного функціонування фінансово-бюджетноі системи

3. Бюджетні інтереси юридичних осіб - це інтереси комерційних і некомерційних (громадських, бюджетних, партійних та ін.) організацій. Інтереси можуть бути 
некомерційними - орієнтованими на надання суспільних послуг, і комерційними - 3 метою отримання прибутку. Важливо відзначити, що серед різних груп носіїв бюджетних інтересів - комерційних, бюджетних, громадських організацій, політичних партій, переважають комерційні інтереси, що пов'язано з високою розвиненістю лобізму комерційних інтересів окремих структур у процесі складання, розгляду і затвердження бюджету, а також із значною корумпованістю владних структур, які мають повноваження щодо ухвалення бюджетних рішень.

4. Бюджетні інтереси конкретної особи є окремим рівнем вияву бюджетних інтересів. Вони виділяються з маси суспільних потреб своєю індивідуальністю. I якщо в загальному сенсі під соціальним захистом мається на увазі турбота держави і суспільства про тих громадян, що потребують допомоги у зв'язку з віком, станом здоров'я, соціальним станом, матеріальною незабезпеченістю, то окремий громадянин розглядає соціальний захист через призму певного набору своїх особистих потреб у державній підтримці, сформованого за індивідуальною ієрархією цих потреб і відповідно до своїх особистих соціальних пріоритетів.

Це означає, що для кожної людини потреби в державній підтримці (тобто бюджетні інтереси) є індивідуальними і набувають особливого статусу в загальній системі суспільних потреб. Таким чином, бюджетні інтереси конкретної особи - це ії пріоритетні потреби, що задовольняються через підтримку держави 3 бюджетних коштів.

Важливо відзначити, що можливість задоволення кожною з чотирьох груп власних бюджетних інтересів при формуванні бюджетної політики прямо залежить від рівня їх впливу на бюджетний процес у частині декларування і закріплення власних інтересів в бюджетній сфері.

Цим пояснюється формування структури бюджетних інтересів, яка характеризується насамперед врахуванням інтересів держави і окремих впливових юридичних і фізичних осіб та меншим ступенем уваги до інтересів суспільства і окремих соціальних груп.

Висновки. Визначено категорію "бюджетні інтереси" як сукупність бюджетних потреб носіїв інтересу, які реалізуються через бюджетну діяльність суб' єктів, спрямовану на отримання певної вигоди через бюджет з метою забезпечення функціонування і розвитку суспільства і держави, юридичних і фізичних осіб.

Визначення бюджетних інтересів як сукупності бюджетних потреб обумовило необхідність визначення категорії "бюджетні потреби" як необхідність (потребу) в бюджетних коштах для досягнення і підтримки певного рівня життєдіяльності індивіда, соціальної групи, суспільства, а також звичайного функціонування держави і юридичних осіб.

Здійснено класифікацію бюджетних інтересів як елемента системи економічної безпеки в бюджетній сфері. Обгрунтовано, що істотне значення в процесі гарантування економічної безпеки в бюджетній сфері має класифікація бюджетних інтересів за носієм інтересів за чотирма групами інтересів: бюджетні інтереси держави - інтереси, носіями яких є державні і місцеві владні структури (органи); бюджетні інтереси юридичних осіб - інтереси комерційних і некомерційних (громадських, бюджетних, партійних та ін.) організацій, які можуть бути некомерційними - орієнтованими на надання суспільних послуг, і комерційними - метою яких $є$ отримання прибутку; бюджетні інтереси окремої особи - пріоритетні потреби конкретної особи, що задовольняються через підтримку держави з бюджетних коштів і виділяються з маси суспільних потреб своєю індивідуальністю.

\section{Список використаних джерел}

1. Абалкин Л. И. Россия: поиск самоопределения : = Russia in search for identity : Очерки. М.: Наука, 2002. 424, [4] с.

2. Барановський О. I. Фінансова безпека в Україні (методологія оцінки та механізми забезпечення): моногр. К.: КНТЕУ, 2004. 759 с.

3. Єрмошенко М. М. Фінансова безпека держави: національні інтереси, реальні загрози, стратегія забезпечення. К. : КНТЕУ, 2001. 309 с.

4. Бондарук Т. Г. Бюджетне регулювання в системі забезпечення економічної безпеки держави // Розвиток системи обліку, аналізу та аудиту: теорія, методологія і організація. Київ: НАСОА, 2013. С. 143-152. 
5. Місцеві фінанси: підруч. // За ред. О. П. Кириленка. К.: Знання, 2006. 677 с.

6. Розвиток бюджетної децентралізації в Україні: наук. доповідь // За ред. д-ра екон. наук I. О. Луніної; НАН України, ДУ “Ін.-т екон. та прогнозув. НАН України". K., 2016. $70 \mathrm{c}$.

7. Бутаев К. А. Бюджетные интересы переходной экономики: проблемы согласования. Ставрополь: Б.и., 1999. 24 с.

8. Закон України “Про основи національної безпеки України" № 964-IV, 19.06.2003 // Відомості Верховної Ради України (ВВР), 2003, № 39, ст. 351.

9. Словари на Яндекс.РУ [Электронный ресурс] / Интернет-служба «Яндекс». Электрон. дан. URL: www.slovary.yandex.ru. - Загл. с экрана.

О. С. БОНДАРУК, acnuранm,

Национальная академия статистики, учета и аудита

\section{Классификационные особенности бюджетных элементов экономической безопасности}

В статье проанализированы теоретические аспекты экономической безопасности во взаимосвязи с такими бюджетныли элементами как «бюджетные интересы» $u$ «бюджстные потребности». Обосновано, что категории «бюджетные интересы» $u$ «бюджетные потребности» занимают ключевые позиции в теории экономической безопасности в бюджсетной сфере, поскольку играют ведуиую роль в прочессе выбора стратегии ее обеспечения. Осуиествлена классификация бюджетных интересов по различным признакам в контексте их влияния на экономическую безопасность государства.

Ключевыеслова: экономическая безопасность, бюджсетные интересы, бюджстные потребности, риски, угрозы, субъекты интересов.

O. S. BONDARUK,

Post-graduate student,

National Academy of Statistics, Accounting and Audit

\section{Budget Elements of Economic Security: Specifics of Classification}

Theoretical aspects of economic security in conjunction with budget components such as "budget interests" and "budget necessities" are analyzed. Key positions of the categories "budget interests" and "budget necessities" in the theory of economic security in the budgetary area are substantiated given their priority role in setting up its implementation strategy. The category "budget interests" is defined as the system of budget necessities of the interest holders, implemented through budget activities of entities and aimed at seeking benefits through the budget, in order to guarantee functioning and development of the society, the state, legal entities and physical persons. "Budget necessities" are defined as the need in budget funds to achieve and sustain, at a certain level, life activities of individuals, social groups, society, state and legal entities. Classification of budget interests by various criteria is made in the context of their impact on the economic security of the state. It is demonstrated that the four-tier classification of the budget interests by interest holder is essential to guaranteeing economic security in the budgetary area: budget interests of the state: the interests held by central and local power offices; budget interests of legal entities: the interests of profit and non-profit (public, budgetary, party and other) organizations; budget interests of individuals: basic necessities of individuals, met by budget transfers, which stand out of the array of public necessities by their individual character. holders

Keywords: economic security, budget interests, budget necessities, risks, threads, interest

Посилання на статтю:

Бондарук О. С. Класифікаційні особливості бюджетних елементів економічної безпеки // Науковий вісник Національної академії статистики, обліку та аудиту: зб. наук. праць. 2017. №1-2. С. 93-99. 